\title{
Correction to: An Age-Period-Cohort Approach to the Incidence and Evolution of Overeducation and Skills Mismatch
}

\author{
Esperanza Vera-Toscano $^{1}$ (D) Elena C. Meroni ${ }^{2}$
}

Published online: 20 November 2020

(c) Springer Nature B.V. 2020

\section{Correction to: Social Indicators Research https://doi.org/10.1007/s11205-020-02514-5}

In the original publication of the article the affiliation of Dr Elena C. Meroni was published incorrectly and the same has corrected here.

European Commission, Joint Research Centre (JRC), Ispra, Italy

Publisher's Note Springer Nature remains neutral with regard to jurisdictional claims in published maps and institutional affiliations.

The original article can be found online at https://doi.org/10.1007/s11205-020-02514-5.

Esperanza Vera-Toscano

e.veratoscano@unimelb.edu.au

Elena C. Meroni

elena.meroni@ec.europa.eu

1 Melbourne Institute: Applied Economic and Social Research, Faculty of Business and Economic, The University of Melbourne, Melbourne, Australia

2 European Commission, Joint Research Centre (JRC), Ispra, Italy 